\section{Boštjan BUGARIČ \\ Transformation of public space, from modernism to consumerism}

\section{Introduction - the demise of centrality in contemporary cities}

Public spaces in contemporary cities are under the pressure of capital and privatisation. Capital interests are transforming its social and physical form. The supremacy of new economic and social values, inherent to modern lifestyle, manifests itself by the disappearance of public spaces in cities. Flexible forms of economic organisation and hyper-production have resulted in transformation of social urban contents. Urban development areas have been internationalised by concentration of capital and globalisation; global values prevail over local spatial characteristics. Soja (2000) speaks about globalisation on the local and localisation on the global level; both also bear negative possible consequences. Public space, which was in modernist times founded on democratic concepts, is transforming into an internationalised space devoid of identity. Global characteristics substitute local ones; such spaces are too small to withstand the competition of global norms. Urban centres, in the modernist times bearers of identity, have in present times transformed into peripheries, while the periphery is becoming ever more central. (Soja, 2000) Because of the concentration of power, (hyper) production and distribution of capital, contemporary cities, although conceptualised on modernist traditional ideals, are becoming the production framework for commercial social contents. Capitalism is stimulating the emergence of a very new urban form - the metropolis that is the peak of development of urban space. Such development is complemented by consequences, such as over-population, social segregation and enhanced pollution. The metropolis is driven by power from capitalist organisation, which is based on constant accumulation of capital and not principles of sustainable development.

Urban sprawl was best studied on cases of large cities in USA, however recently even European cities have also become subject to so called americanisation of space, whereby centres are changing into abandoned areas, while the periphery is developing attractive commercial programmes. The vehicle of transition from the industrial to the post-industrial era carries two development processes in the transformation of historical urban cores. The first is seen as degradation and abandonment of spaces because of lack of social contents, while the second is introduction of new organisational forms, tailored to capital needs, which exclusively service consumption. City centres cannot successfully compete with rapidly growing consumerist contents of the periphery. Migration processes of contents from urban centres to the periphery are accelerated by lower building costs, possibilities for land speculation, better access with adequate parking spaces, whereby better transport arrangements ensure quicker connections. This migration process has affected decentralisation of urban functions, i.e. the city centre is losing its primary and central function. The city is no longer subdivided in the functionalist manner into zones for living, work, recreation and leisure; incompatible contents [1] now share the same space. Capital interests are of key importance for such development, individual desires don't bear much weight. City centres are rather uninteresting for development, since many rigorous conservation measures are applied, renewal is a financially demanding operation and dilapidation also helps social segregation take force. Emptying of city centres is especially conditioned by distance of contents and quality of communication. Well-thought out and successful placement of capital into development of varied programmes in the periphery, which affect constancy and attractiveness of events, increase visits and urban consumption, since the contents are adapted to user desires.

With the onslaught of pertaining cultural, administrative and even residential functions, [2] powers of the consumerist city are increasing. By various simulations amassment of capital is also expressed in physical form, which copies programmes in city cores. With these consumerist cities the modern consumer enters hyper-reality, which was as the simulacrum concept forecasted by Baudrillard (1999). Copies of original cities represent simulations of city contents, which at a certain point transform into simulacra [3] or fakes that never existed (Baudrillard, 1999). Simulacra of new social relations are places of consumption that are oriented towards amassment of capital. This principle doesn't offer the user sustainable satisfaction, "since possibilities in their world are endless and the quantity of tempting, offered goals cannot be exhausted «. (Bauman, 2002, 93) Because of attractive content and functional satisfaction of consumer needs (all activities are in one place, unlimited parking possibilities, better price performance of offered goods) the user prefers to frequent such places. Yet, amidst the occurring constant aggressive visual sensations from advertising, objective assessment of reality is lost and the ongoing privatisation of public space made un-discernable.

De Cauter (1998) states that capital interest conditions development of spatial development systems, in the sense of centrality overpowering periphery. This development model stems from »disneyfication « of city centres and »bronxification « of urban peripheries. Two urban poles emerge that develop completely autonomously with completely new social structures of inhabitants and users. Urban actors become puppets of economic interests held by the affluent few, which direct development of public space.

Because of urban sprawl into the hinterland self-sufficient (sub) local centres emerge and city centres gradually loose their social content. The city's identity is transferred to urban areas that are more attractive, allow more visitors and ensure constant happenings. Urban locales [4] therefore move to places of consumption where certain cultural, education and administrative function of the new city develop. By adding entertainment and administrative activities self-sufficient centres appear, which are nevertheless mostly occupied by commercial contents. Because of their higher attractiveness, constant happenings, greater media coverage and advertising, locales in consumer cities are more frequented than those in city cores. Constant inflow of capital to these places allows self-organisation and the maintenance of a web of functions, which were formerly the operational domain of city cores (administration, culture, entertainment). 


\section{From the modernist tradition to privatisation of the public}

The modernist architectural approach to spatial organisation closely followed the spirit of modern lifestyle, which was a derivative of the functionalist motto "Form Follows Function «[5]. In this context public space was designed as an organised system where development ensued according to functionalist rules. Similar totalitarian arrangements within designed public space were known already earlier, in the transitory period when the proletariat moved settled in the city. Urbanism, an applicative science of the bourgeoisie class, was used as a tool for disciplining the anonymous working class. By using principles of economic sciences space was mastered and for a short time chaotic development and expansion of cities were curtailed. The capability of applying management system of modernist cities to control the individual was the seed of economic mastering of public space, which we are presently subject to. Individuals that were formerly controlled only during working hours and at the work place are nowadays controlled in the entire public realm constantly. Shopping centres are subject to even stronger control scrutiny.

Privatisation of public space hinders possibilities for democratic decision-making about spatial issues. Public spaces are no longer intended for the public, meaning gradual transformation of places into non-places. Places are parts of cities that express identification needs. According to Augé (1999) places express relations of identity and historical hypotheses. Visitors or users can recognise certain segments of their own history and discover ties that link them to other members of the same place, meaning nourishment of social bonds. Contrary to a place, a non-place doesn't bear symbolic expression, which could reflect identity, relations or historical predispositions. Bauman (2002) claims that non-places are presently occupying larger shares of physical space although they are only used for transiting, and usually vacated very quickly. The most common examples of non-places are shopping centres, airports, highways, anonymous hotel rooms, public communication terminals etc. In non-places the distinction between public and private is weak, public spaces become private places of consumption. Contrary to initiative individualism, inherent to early capitalist ideology, contemporary consumerist individualism is passive, thus even contemporary public space cannot be different. (Auge, 1999)

Le Corbusier's definition of the architect as a social reformer included the hypothesis that capital will contribute to the mass production of homes, thus settling the problem of poor living conditions amongst the less affluent population. However he never critically questioned the potential role of capital, which can apply its flexible, content to expand and completely take over control of the modernist spatial framework. [6] In this case the professional side of urban planning has its hands tied, leading to unbalanced and uncontrolled urban development. Thus the functionalist motto »Form Follows Function « was replaced with the postmodernist »Form Follows Finance «[7] - public spaces became the battleground of capital. In contemporary cities organisation of public space is executed on the level of economic and political decisions, independent of urban planning regulation. Organisation of activities in public space manifests itself as part of the serial production of banality. Debord (1999) actually defines the spectacle as the rationale of any opera- tional social-economic arrangement, which therefore dictates the schedule of all events in the city.

In the contemporary city the individual is trapped in the passiveness of capitalist individualism, where, blinded by consumerist utopia one is incapable of judging, what is important. Jameson (2001) stresses that development of consumerist capitalism so far constitutes the purest form of capital, which colonises new territories. Public space in the service of consumption - the driving activity of social life transforms into controlled space. "The city is becoming the framework of private retail and public space is an integral part of this privatisation « (Madanipour, 2003, 238) Urban planning regulation cannot master and direct development according to public or professional needs, since it is caught in capital investment interests. Urban planning is in fact often subordinate to interests of investment. Reforms that link the profession exclusively to the economy are taking away even more of its autonomy. The profession is connected to the economy in ways that are often questionable and in many ways negative. The profession has actually been relieved the possibility of criticising unacceptable development. Planning products, under pressure of capital, dictate special forms of representing public space, in which even social contents are purposely controlled. According to their use, public spaces are divided into those to be used by the upper and those for the lower classes. Types of events are planned and clearly delimited. Public spaces are losing their use and becoming the property of private companies, more than public spaces as such. Spaces organise din this fashion are carefully controlled, the city is turning into a set (for a show) of capital, where events are mirrored in the eye of an invisible camera.

\section{Disappearance of the public person}

Touristification and citisation are processes that significantly mark the contents of public space. They bring two types of organised capital, which disable development of a variety of social contents and support only specified types of activity. Excessive development of tourism implies degradation of content for the inhabitants of such areas. Undoubtedly tourism can accelerate revitalisation of dilapidated urban areas, but because of the quantity of commercial players, only transformation for tourism offer purposes happens. (Hočevar, 1998) Tourism is the applied vehicle for attracting capital into cities over a short period of time, with no respect for the needs of the inhabitants. Graafland (2000) states that the tourism industry is becoming the most important source of revenue, but also implying many negative factors caused by increasing quantity of tourism contents, for the local population. "Touristification is especially common for Slovene Mediterranean cities. The spatial assets have been used for tourism, which to a certain extent is beneficial for the area's development. The problem starts when tourism contents become the most important economic discipline in the city. Negative factors are introduced, such as: loss of identity because of lack of indigenous population, issues connected to transport infrastructure developments and pollution. With intensification of tourism activities, the quality of life in cities decreases'. (Bugarič, 2006, 62).

Another example of capital organisation within a given urban area is the process of citisation or business revitalisation, by which the city core changes into a business centre. 
The citisation process introduces uniform business activities and thus diminishes attractiveness of the place for other activities, buildings become inaccessible because of increased rents, public spaces become semi-private and empty in the evenings, after business hours. (Hočevar, 1998) These places are characterised by monotonous flux. Coupled with this process, residential functions are gradually removed from city cores, homes are transformed into offices or administration premises. Such areas emerge because of lack or weakening of performative and representative functions of central city spaces, as put by Hočevar (2002), furthermore, thus the public human disappears, which is also a logical consequence of the disappearance of public spaces.

With its exceptional capacity to adapt, capital contents easily fit into any urban situation and despite social needs create simulated environments and artificial places, where communication with the outside world is minimalised. (De Cauter, 1998) Thus specific development systems emerge in a place, which create their own brand names that have no respect for spatial characteristics or its users.

\section{Historical through modern to consumerist}

On the example of the city of Koper we can emphasise the key facts that prove privatisation of public space. Modernism tried to define the new physical structure for the new social structure in the city (proletariat) and discontinue the bourgeoisie tradition of medieval palaces, but today manifests itself only as a mirage of social equality. Development of Koper was strongly influenced by modernism, yet with even stronger ideological connotations. The socialist order in Yugoslavia also determined spatial development, which was on the urban planning level the ideological apparatus for managing social relations in the city. This is contrary to Corbusier's classical functionalism, which provided niches for urban development with new capital.

Let us return to the real example of Mihevc's urban planning. His proposal for rehabilitating the old town core from 1967 suggested real and methodical demolition of old buildings, whatever their historical value. Such development was advocated by the fact that the modern city needs new housing for the modern man. The functionalist era planned many drastic developments in the historical core, which were never fully completed. The demolishing of older housing along the town core's edge was proposed, which should make place for new high-rise housing for the needs of the workers. The first skyscrapers built by Mihevc in 1958 already influenced the old city silhouette, since they competed with the formerly dominant church bell-tower, causing outcry from the conservationists and strong criticism. The skyscrapers would fully utilise the ground's loadbearing capacity, more space would be left over for greenery, the town would be better ventilated and there would be more sunlight. According to the urban master plan skyscrapers were supposed to surround the entire old town core. (Koselj, 1995) The islands structure conditioned building of larger palaces in the central part of the town core and housing structures towards the edges, where the ground's load-bearing capacity was lesser. More than to new functions, the skyscraper project was a contribution to the town's new ideology - workers were the beneficiaries of a new housing form - the skyscraper. The project began with one skyscraper on Nazor's Square. Because of unacceptable plans for demolition the project was stopped and in 1967 conservationists Murko and Rotar prepared a new rehabilitation plan for the town core. ${ }^{[8]}$

Changes in the demographic structure of the city core of Koper followed the changes of context of the functionalist city. Because of emigration the population structure became monotonous and demanded less complementary programmes, such as culture, sports and education). This is the main reason for abandonment of programme variety and activities in the city core. Because of constant migration, development of collective identity was disabled, something that is usually formed in places with permanent residents.

The modern image of city expresses unbalanced actions of urban actors. In Koper incompatible systems meet in a relatively very compact area - city core, city of consumption and industrial area of the port. The city core itself is in very bad state, since its utilities infrastructure is rather weak; it also shows lack of social contents. Ownership of buildings is also a problem, meaning that documentation is disorganised and the buildings badly maintained or deserted. The prevailing administrative function, which is a remnant of the first citisation and bureaucratic use of the city core, activates the city core only during working hours. The spatial development plan is subordinate to capital interests and political decisions, relations between economic actors and civil society are vague, ${ }^{[9]}$ management of public spaces is subject to gradual privatisation. Instead of Mihevc's ideological project of a bastion of skyscrapers, today the view of Koper is blocked by shopping centres and port infrastructure. Capitalist hyper-urbanism manages development without plans since capital is the main generator of social events. The city itself is not excluded, but the flux has been taken away from the shaded Mediterranean stone alleys and transferred to the neon-lighted shopping centres on the city's edge.

In modernism form prevailed over long-term development of urban content. Because of form being emphasised modernism created the ideal foundation for development of rapidly changing forms, typical for consumerist cities. These bloom from adaptability of capital contents and don't follow spatial directions. Moreover, they can quickly overgrow urbanistic norms. As we can see on the case of Koper, the decisive role in preventing execution of the ideological modernist layout was played by the profession. Economic hyper-urbanism creates carefully controlled totalitarian spaces, where the individual is lost in the reality of a virtual public space. Production of such spaces flexibly adapts to any economic need of mass production, while traditional, rigid urbanism is in this important segment of city planning, gradually losing any decision-making capacity.

Dr. Boštjan Bugarič, architect

E-mail: bostjan.bugaric@guest.arnes.si

\section{Notes}

[1] A typical example of combining incompatible contents that is based on capital interests, is the case of consumption in Koper, which is being developed on the edge of the protected nature reserve Škocjanski zatok. The shopping centre Supernova actually shares a parking lot with the town prison. 
[2] Besides retail contents, some shopping centres in the USA integrate city-building contents, such as theatres, churches, hotels etc. (Strong, 2003)

[3] A simulacrum is a copy, imaginary condition (act), which appears real (Baudrillard, 1999).

[4] Urban locales as defined by Hočevar (2000) are places with intentionally or unintentionally constructed events that occur in open or closed public spaces and private places with public access. The placed temporary or permanent situational settings increase their attractiveness and stimulate involvement in the place's issues. Hočevar (2000) describes urban locales as a unity of functional, symbolic-signifying and formal-design dimensions of performative action and a certain pattern of social (re)production of space in the city.

[5] Form follows function.

[6] The investors of modernist architecture for office and administrative buildings, developed in the 1950s in the USA, were large corporations. They represent the framework of capitalist operation, while social orientation is being lost.

[7] Form follows finance.

[8] In the same year the National agency for safeguarding monuments produced a conservation document with inventory and categorisation of cultural monuments in the Koper town core. The document was produced by dr. Curk, dr. Komelj, dr. Sedej, dr. Šumi and dr. Zadnikar. The inventory contained the building stock of the town core with topographic treatment of monuments and most important urban places. It covered the territory of the historical town core and housing estate Semedela, still under development at the time.

[9] The facade of the new primary school on Bonifika, which replaced Mihevc's modernist one, carries a political manifesto. Its front facade bears the share of support for the present local government and word »Thanks «. A public building has become the bearer of the present government's political will.

\section{List of figures:}

Figure 1: Example of incompatible linkage of contents by the nature reserve in Koper - the shopping mall and town prison share a common parking lot. (Foto: Grögl, 2004)

Figure 2: Based on division of programmes, urban locales are designed in various city quarters (Source: Bugarič, 2006)

Figure 3: The silhouette of the Koper town core in time. (Source: Guček, 2000)

Figure 4:Proposal for the rehabilitation of the Koper town core and proposal for new development. (Source: Guček, 2000)

Figure 5: Simulation of the Koper townscape based on the development of the consumer city. (Source: author)

Figure 6: Mihevc's skyscraper demolishes scales in the old town core. (Photo: Grögl, 2004)

For literature and sources turn to page 11.

Translated by Ivan Stanič.

\section{Aleksander Jakoš \\ Ljubljana - Phases of Urban Development}

\section{Introduction}

The emergence of the first settlement (Emona) on the territory of the present Ljubljana was conditioned by its geographical position near the Ljubljanica river and between Polhograjsko hribovje (the Polhov Gradec Highlands) and Posavsko hribovje (the Posavje Highlands).

Because of its defensive character the town was a long time spatially limited. In 1800 Ljubljana had around 10.000 inhabitants. The tearing down of the last ramparts towards the end of the $18^{\text {th }}$ century was very important for the development of Ljubljana as it was liberated from the medieval bonds. The town began to spread and the number of inhabitants increased rapidly. The town seeped into the nearby suburbs that became a part of it (e.g. Spodnja Šiška, Trnovo, Vodmat) and in the year 1948 the town had nearly 100.000 inhabitants. Agricultural land separated the town from other nearby settlements which are now an integrating part of the Municipality of Ljubljana. Around 25.000 inhabitants lived in those settlements which equated to a quarter of the population of the town itself. Altogether, the 1948 Census enumerated 123.149 inhabitants on the territory of the Municipality of Ljubljana. Morphologically speaking, Ljubljana was a compact town with 100.000 inhabitants and a fairly clear boundary line between itself and neighbouring settlements. Then commenced the development of the modern, present-day Ljubljana which began to expand, and the town limits are ever more difficult to determine since urbanisation altered the nearby settlements. Urbanised landscape expands especially along radial motorways and reaches far into the territories of other communes.

After the World War II the development of Ljubljana went through characteristic phases of urban development:

- urbanisation

- counter-urbanisation

- reurbanisation

Ljubljana developed similarly to other European capitals in the periods of industrialisation and deagrarisation. Growth of towns was initially conditioned by industrialisation, and an ever-faster deagrarisation after World War II sped up the growth of towns and urbanised their surrounding areas. Greater population mobility (traffic) made suburbanisation possible. The following two phases were not so distinctive in Ljubljana and have practically still been going on simultaneously. But we can denote counter-urbanisation as an escape from town because of the cost of life (lodging), which means that the cost of municipal services has exceeded the effects of the city-building activities. Reurbanisation, however, is a process brought about consciously in order to restore values as well as life into towns.

As for Ljubljana we can say that in the first two phases it developed by the book. The third phase manifests itself clearly in migrations from the town, but it hasn't reached the phase of physical degradation of individual town sections. 